\title{
Head-to-head agglutination of ram and boar epididymal spermatozoa and evidence for an epididymal antagglutinin*
}

\author{
J. L. Dacheux $\ddagger$, M. Paquignon $\uparrow \S$ and Y. Combarnous $\dagger$
}

$\dagger$ †.N.R.A., Station de Physiologie de la Reproduction, Nouzilly, 37380 Monnaie; $\ddagger$ C.N.R.S. Laboratoire de Physiologie Comparée, Faculté des Sciences, 37200 Tours; and §I.T.P., 149 rue de Bercy, 75595 Paris, France

\begin{abstract}
Summary. Spermatozoa from the corpus epididymidis of boars and rams showed headto-head agglutination when diluted. The occurrence of agglutination coincided with the appearance of motility but preceded the ability to bind to zona-free hamster eggs. Head-to-head agglutination was inhibited by the addition of caudal epididymal plasma. A protein acting as an antagglutinin on spermatozoa from the corpus epididymidis was extracted from cauda epididymal plasma and partly purified.
\end{abstract}

\section{Introduction}

The development of fertilizing ability of spermatozoa in several mammalian species depends on modifications that may occur during their passage through the epididymal duct (Bedford, 1966; Orgebin-Crist, 1967). These modifications affect motility (Gaddum, 1968), morphology (Olson \& Hamilton, 1978), metabolic patterns (Voglmayr, Scott, Setchell \& Waites, 1967; Dacheux, O'Shea \& Paquignon, 1979) and the surface properties of cell membranes (Bedford, 1963; Nicolson, Usui, Yanagimachi, Yanagimachi \& Smith, 1977; Lewin, Weissenberg, Sobel, Marcus \& Nebel, 1979; Suarez, Hinton \& Oliphant, 1981). For all these changes, the corpus epididymidis is a critical region, especially for the development of fertilizing ability and sperm motility (Dacheux \& Paquignon, 1980; Orgebin-Crist, Olson \& Danzo, 1981). In this study, we followed the degree of head-to-head agglutination observed when sperm samples are diluted. These observations for sperm samples from several regions of the epididymis were correlated with the development of sperm motility and with the ability of the spermatozoa to bind heterologous eggs in vitro.

\section{Materials and Methods}

Materials. Epididymides were obtained from 5 adult boars (Large White) and 18 rams (Ile-deFrance). Spermatozoa were removed from 10 regions of the epididymis by section of the organ with a razor blade and collecting the exuded fluid in Krebs-Ringer-bicarbonate (KRB) (Imai, Niwa \& Iritani, 1977). The samples were diluted to achieve a final concentration of 10-50 $10^{6}$ spermatozoa/ml. Some sperm samples from the corpus epididymidis were collected by cannulation of a small area of the epididymis by the technique described by Dacheux (1980). Samples of rete

* Reprint requests to Dr J. L. Dacheux, I.N.R.A., Station de Physiologie de la Reproduction, Nouzilly, 37380 Monnaie, France. 
testis fluid from boars or rams were obtained by cannulation of the testis (Voglmayr, Waites \& Setchell, 1966; Dacheux et al., 1979). Plasma from the cauda epididymidis was collected by retroflushing the tubule of the posterior cauda (Zones 10 and 9, Text-fig. 1) with paraffin oil. After centrifugation $\left(30 \mathrm{~min}, 1500 \mathrm{~g}\right.$ ), the fluids were stored at $-20^{\circ} \mathrm{C}$ until used. The protein in the various fluids was prepared by precipitation with ethanol (Franchimont, Chari, Hazee-Hagelstein, Debruche \& Duraiswami, 1977) or by freeze-drying after dialysis against distilled water.

Motility estimation. The motility of the spermatozoa was estimated as the percentage of mobile spermatozoa after a 10 -min incubation at $37^{\circ} \mathrm{C}$ before agglutination had begun, using a $0.1 \mathrm{~mm}$ depth cell (Dubois et al., 1975; Jouannet, Volochine, Deguent, Serres \& David, 1977) in a Laser Doppler Velocimeter using the SORO 200 Spermokinesimetre (SORO, Arcueil, France).

Agglutination estimation. The intensity of head-to-head agglutination of spermatozoa was estimated under a phase-contrast microscope after incubation for $1 \mathrm{~h}$ at $37^{\circ} \mathrm{C}$. Free spermatozoa were counted in a haemocytometer before $\left(\mathrm{F}_{0}\right)$ and after $\left(\mathrm{F}_{1 \mathrm{~h}}\right)$ the incubation. The percentage of agglutinated spermatozoa was calculated as $100 \times\left(\mathrm{F}_{0}-\mathrm{F}_{1 \mathrm{~h}}\right) / \mathrm{F}_{0}$.

Sperm binding to zona-free hamster ova. Zona-free hamster eggs have been reported to exhibit high affinity for the spermatozoa of many mammalian species (Yanagimachi, Yanagimachi \& Rogers, 1976; Hanada \& Nagase, 1981), including those of the boar (Imai, Niwa \& Iritani, 1977, 1979,1980 ), and such ova were used to assess in vitro the fertilizing ability of boar spermatozoa.

Oocytes were obtained from golden hamsters which were induced to superovulate with an intraperitoneal injection of PMSG and hCG, as reported by Imai et al. (1977). A cumulus mass was recovered from the ampullary portion of the oviducts, and treated with hyaluronidase to disperse the granulosa cells and with trypsin to dissolve the zona pellucida. Zona-free hamster eggs, numbering 10-15, were incubated in $1 \mathrm{ml}$ sample of KRB containing 1-5 $510^{6}$ spermatozoa from each of the 10 different epididymal regions for 3 boars. Motility and agglutination were estimated before the in-vitro insemination. After incubation for $3 \mathrm{~h}$ at $37^{\circ} \mathrm{C}$, binding was defined as the number of spermatozoa adhering to the egg after 2 washes in buffer, followed by fixation with glutaraldehyde (Schmell \& Gulyas, 1980). The numbers of spermatozoa bound per egg and penetrating the eggs were determined by observing the eggs under a phase-contrast microscope.

\section{Results}

\section{Head-to-head agglutination}

This occurred when the gametes present in the distal caput and corpus regions of the epididymis were diluted in $\mathrm{KRB}$ and incubated at $37^{\circ} \mathrm{C}$ (Plate 1). In all of the boars and rams studied, $70-85 \%$ of gametes from the corpus epididymidis were agglutinated after dilution (Text-fig. 1). The agglutinated cells were adherent to each other mainly at their acrosomal regions (Pl. 1, Fig. 3). The spermatozoa from Zones 2 and 3 agglutinated mainly in doublets or triplets and only a few agglutinations of more than four cells were observed. Cells from the corpus region (Zones 4, 5, 6 and 7) were associated at the acrosomal region in clusters of 40-100. In the posterior part of the corpus and in the cauda (Zones 8,9 and 10), the large aggregates disappeared and a few spermatozoa were associated in groups of 2 or 3 cells only. The agglutination was time dependent; it appeared after 15 min and was maximal after $1 \mathrm{~h}$ of incubation at $37^{\circ} \mathrm{C}$. The aggregated spermatozoa were not dissociated by shaking or agitation of the suspension. The presence or absence of calcium ( $5 \mathrm{mM}$ ), EDTA ( $5 \mathrm{mM})$, milk $(20 \%)$ or egg yolk $(5 \%)$ was without effect on head-to-head agglutination of

\section{PLATE 1}

Boar epididymal spermatozoa after incubation at $37^{\circ} \mathrm{C}$ for $1 \mathrm{~h}$ in KRB. The spermatozoa in Figs 1-10 were from Zones 1-10 as indicated in Text-fig. 1. The same pattern was seen for boar and ram spermatozoa. $\times 250$. 
PLATE 1
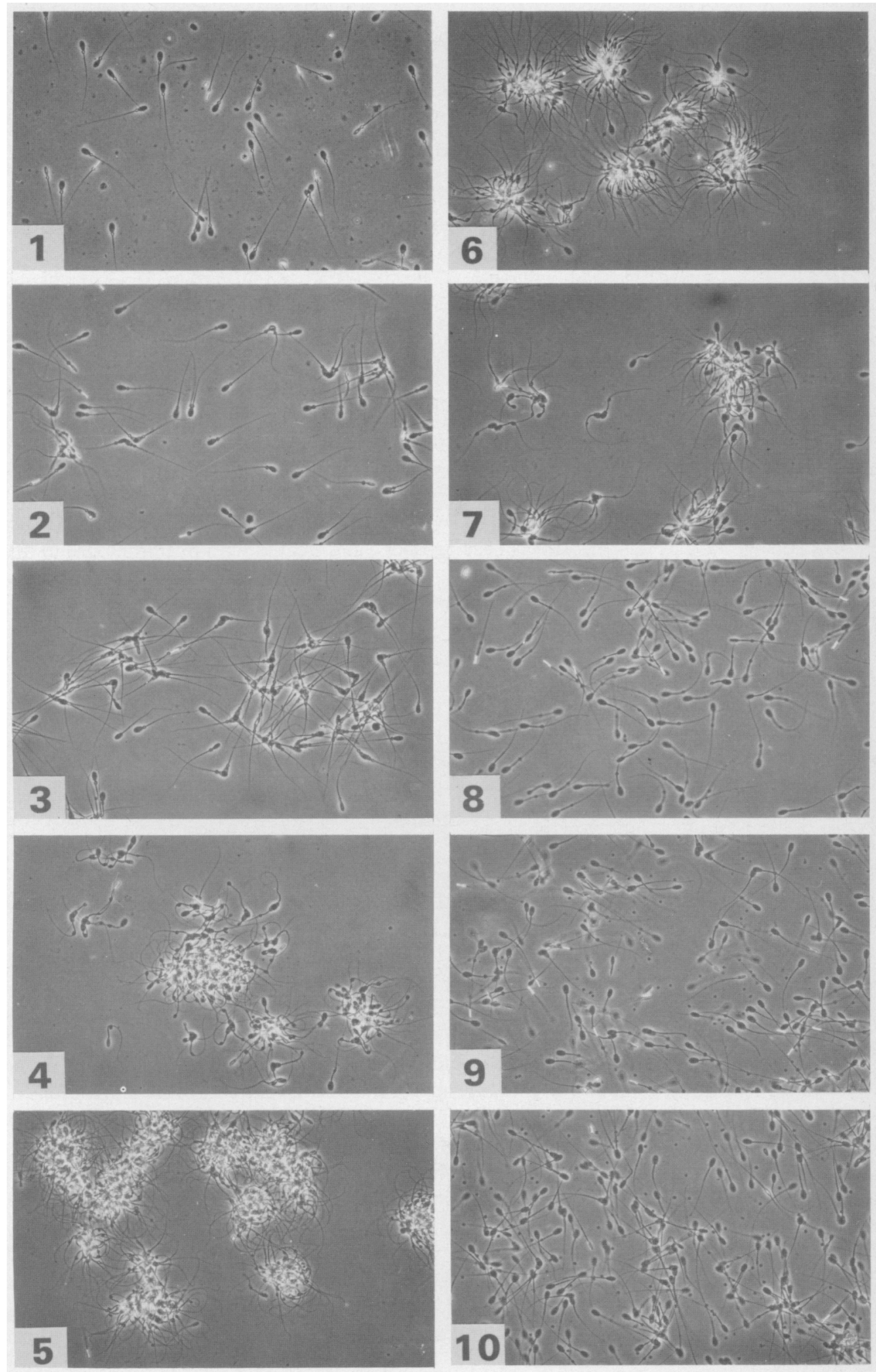


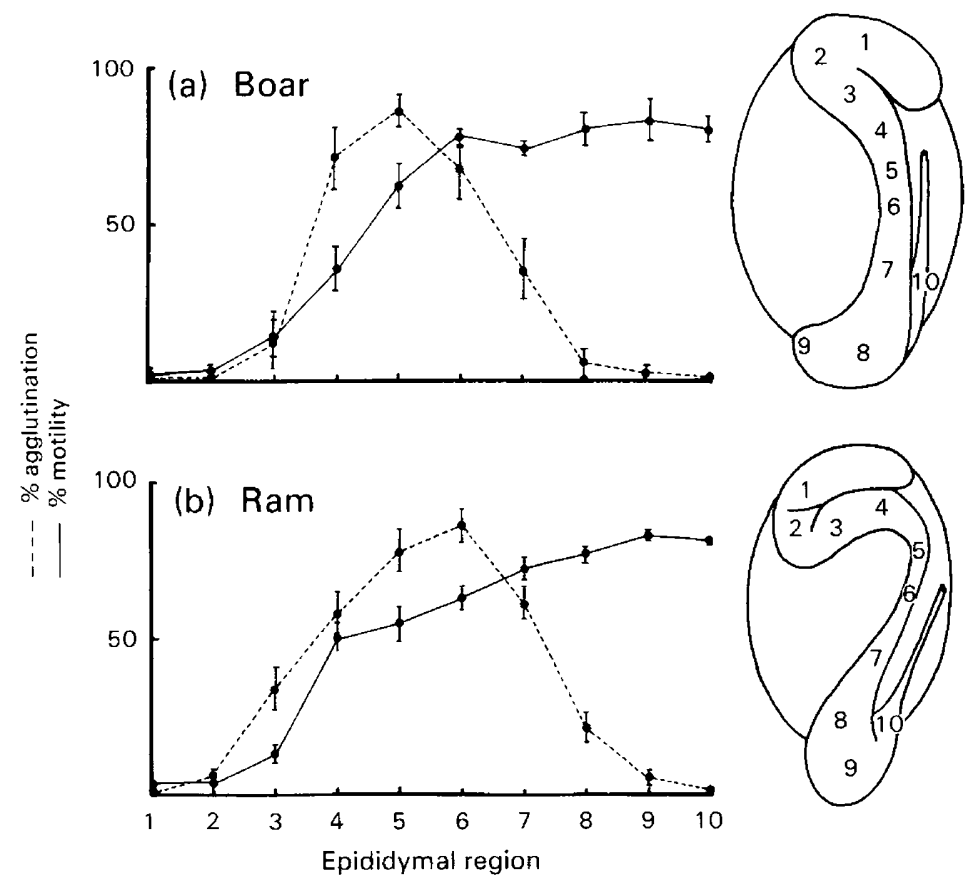

Text-fig. 1. The epididymal origins of the spermatozoa from boars $(N=5)$ and $\operatorname{rams}(N=18)$ (Zones 1-10) and the changes in sperm agglutination and motility.

epididymal spermatozoa. Similar agglutination behaviour was observed when spermatozoa were collected from the corpus epididymidis by cannulation, ruling out any contamination by blood serum. Modification of sperm concentration $\left(10-150 \times 10^{6}\right.$ spermatozoa $\left./ \mathrm{ml}\right)$ was without effect on the intensity of the agglutination.

\section{Boar sperm binding to zona-free hamster eggs}

The ability of boar spermatozoa to bind hamster oocytes appeared in the last portion of the caput (Zone 3) and increased in the corpus (Table 1). In the upper and middle part of this region, the number of spermatozoa per egg did not exceed 100. Intense binding of the spermatozoa to the hamster oocyte began to appear for spermatozoa from the posterior part of the corpus (Zones 6 and 7 ), with 7 and $79 \%$ respectively of the observed oocytes being completely covered with spermatozoa. Spermatozoa from the cauda totally covered the oocytes. No penetration of eggs by spermatozoa were observed whatever their site of origin in the epididymis.

\section{Motility of epididymal spermatozoa}

For rams and boars, the percentage of motile spermatozoa from Zones 3 and 4 (posterior caput and anterior corpus) was increased after incubation at $37^{\circ} \mathrm{C}$ for $10 \mathrm{~min}$ (Text-fig. 1). The spermatozoa from Zones 6 or 7 for the 2 species showed the maximal percentage of motile spermatozoa. The pattern of motility showed qualitative changes according to the epididymal site of origin of the spermatozoa. For spermatozoa from the posterior caput, only the flagella oscillated and very few spermatozoa $(<1 \%$ ) showed progressive movement after a 10 min incubation. For spermatozoa from the corpus, the vibration of the flagella increased and the gametes moved in the medium with a circular or irregular pattern of progression, the head of the gamete exhibiting a 
Table 1. Effect of topographical origin of boar epididymal spermatozoa on their binding to zona-free hamster eggs ( $\%$ of observed eggs)

\begin{tabular}{|c|c|c|c|c|c|}
\hline \multirow[b]{2}{*}{ Region } & \multirow[b]{2}{*}{$\begin{array}{l}\text { No. of eggss } \\
\text { observed }\end{array}$} & \multicolumn{4}{|c|}{$\%$ of eggs with: } \\
\hline & & $\begin{array}{c}0 \\
\text { spermatozoa }\end{array}$ & $\begin{array}{c}1-10 \\
\text { spermatozoa }\end{array}$ & $\begin{array}{c}10-100 \\
\text { spermatozoa }\end{array}$ & $\begin{array}{c}>100^{*} \\
\text { spermatozoa }\end{array}$ \\
\hline 1 & 26 & 100 & & & \\
\hline 2 & 27 & 100 & & & \\
\hline 3 & 30 & 93 & 7 & & \\
\hline 4 & 34 & 60 & 34 & 6 & \\
\hline 5 & 35 & 18 & 76 & 6 & \\
\hline 6 & 36 & - & 17 & 76 & 7 \\
\hline 7 & 38 & - & - & 21 & 79 \\
\hline 8 & 36 & - & - & - & 100 \\
\hline 9 & 15 & - & - & - & 100 \\
\hline 10 & 20 & - & - & - & 100 \\
\hline
\end{tabular}

* Spermatozoa completely covered the eggs and an accurate count was impossible.

rotatory movement out of phase with the flagellar beat. The forward progression and straight-line movement of the gametes appeared in Zones 8,9 and 10. For the ram, this progressive and mature motility was observed for $67 \%$ of the animals (12/18) for spermatozoa from Zone 8 and for $100 \%$ of the animals for spermatozoa from Zones 9 and 10. The spermatozoa from Zones 9 and 10 of all the boars progressed in a straight line.

\section{Inhibition of agglutination by caudal epididymal plasma}

The effect of protein on the intensity of agglutination of epididymal spermatozoa (from Zone 5) was studied with bovine serum albumin and proteins from testicular fluid, caudal epididymal plasma and ejaculated seminal plasma. Testicular proteins and albumin showed no effect on agglutination even with concentrations as high as $20 \mathrm{mg} / \mathrm{ml}$. In contrast, agglutination was reduced when proteins from the cauda or ejaculate $(5 \mathrm{mg} / \mathrm{ml}$ ) were added to the incubation medium (Table 2). This inhibiting effect of epididymal plasma proteins was not dependent on the method of preparation (freeze-drying or ethanol precipitation). The inhibition was not species-specific, as boar epididymal plasma proteins acted on ram spermatozoa and vice versa (Text-fig. 2).

Cauda epididymal plasma proteins not only prevented agglutination when added before incubation but were also able to dissociate previously clumped spermatozoa. Deep freezing and

Table 2. Effect of different proteins $(5 \mathrm{mg} / \mathrm{ml})$ on the occurrence of agglutination of spermatozoa from Zone 5 of the epididymis

\begin{tabular}{cccccc}
\hline & \multicolumn{5}{c}{ Protein* } \\
\cline { 2 - 6 } & Control & RTF & CEP & Ejaculate & BSA \\
\hline $\operatorname{Ram}_{(\mathbf{N}=2)}$ & ++ & ++ & 0 & 0 & ++ \\
$\mathbf{B o a r}$ & ++ & ++ & 0 & ++ & ++ \\
$(\mathbf{N}=5)$ & & & & & \\
\hline
\end{tabular}

$\mathrm{RTF}=$ rete testis fluid $; \mathrm{CEP}=$ cauda epididymal plasma $; \mathrm{BSA}=$ bovine serum albumin. ++ , intense agglutination; + , some agglutination; 0 , no agglutination.

* From the same species as the spermatozoa.

$\dagger$ Three samples showed some agglutination $(+)$, the other 2 gave none. 


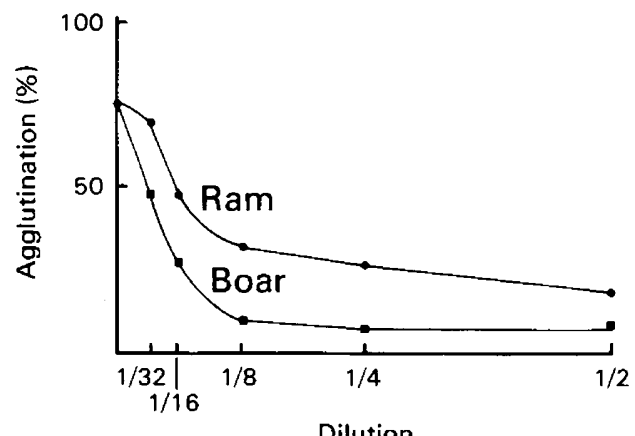

Text-fig. 2. Effect of the presence of various amounts of cauda epididymal plasma diluted in KRB on the percentage of agglutinated epididymal ram spermatozoa from Zone 6.

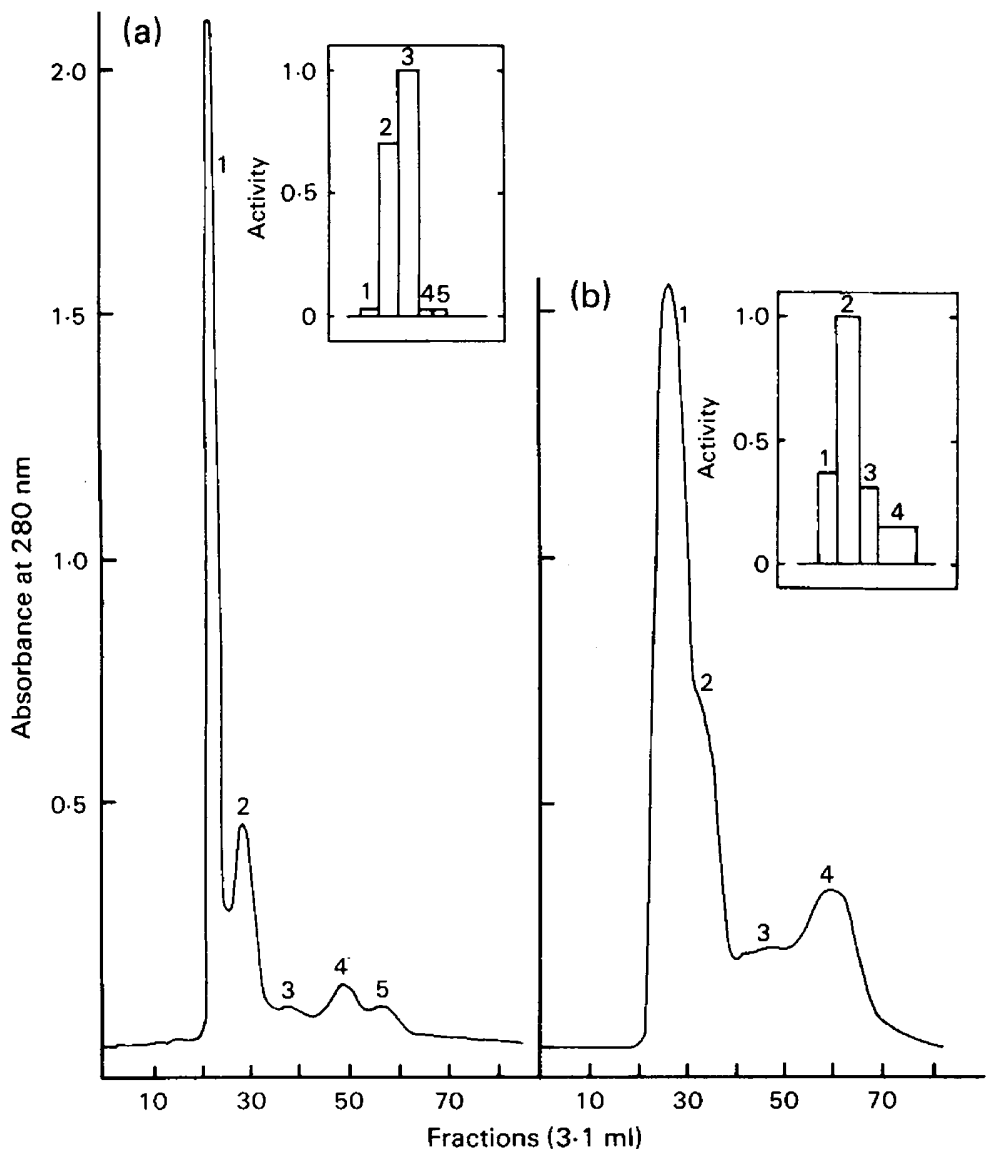

Text-fig. 3. Gel filtration of cauda epididymal plasma from (a) ram and (b) boar on Sephadex $\mathrm{G} 100$. The columns $(2.2 \times 80 \mathrm{~cm})$ were equilibrated in $50 \mathrm{mM}$-ammonium bicarbonate $\mathrm{pH} 8.0$ and were loaded with $2 \mathrm{ml}$ cauda epididymal plasma (a) or $60 \mathrm{mg}$ of dialysed and freeze-dried cauda epididymal plasma. The flow rate of the buffer was $6 \mathrm{ml} \mathrm{h}^{-1} \mathrm{~cm}^{-2}$. The fractions were collected and tested for anti-agglutination activity (see Text-fig. 4). In (b) the yields were 26.6 $\mathrm{mg}$ for fraction $1,9.0 \mathrm{mg}$ for fraction $2,5.2 \mathrm{mg}$ for fraction 3 and $15.3 \mathrm{mg}$ for fraction 4 . 
freeze-drying did not destroy this anti-agglutination activity but heating at $90^{\circ} \mathrm{C}$ for $10 \mathrm{~min}$ and centrifuging at $10000 \mathrm{~g}$ for $20 \mathrm{~min}$ reduced the activity by two thirds.

\section{Partial purification of the anti-agglutination factor from cauda epididymal plasma}

Proteins from the cauda epididymidis plasma from rams and boars were fractionated on Sephadex G-100 (Text-fig. 3). The anti-agglutination activity of these fractions was tested by recording their effect after serial dilutions (Text-fig. 4), and was localized in peaks 2 and 3 for ram (Text-fig. 3a) and in peaks 1, 2 and 3 for boar (Text-fig. 3b) cauda epididymal plasma.

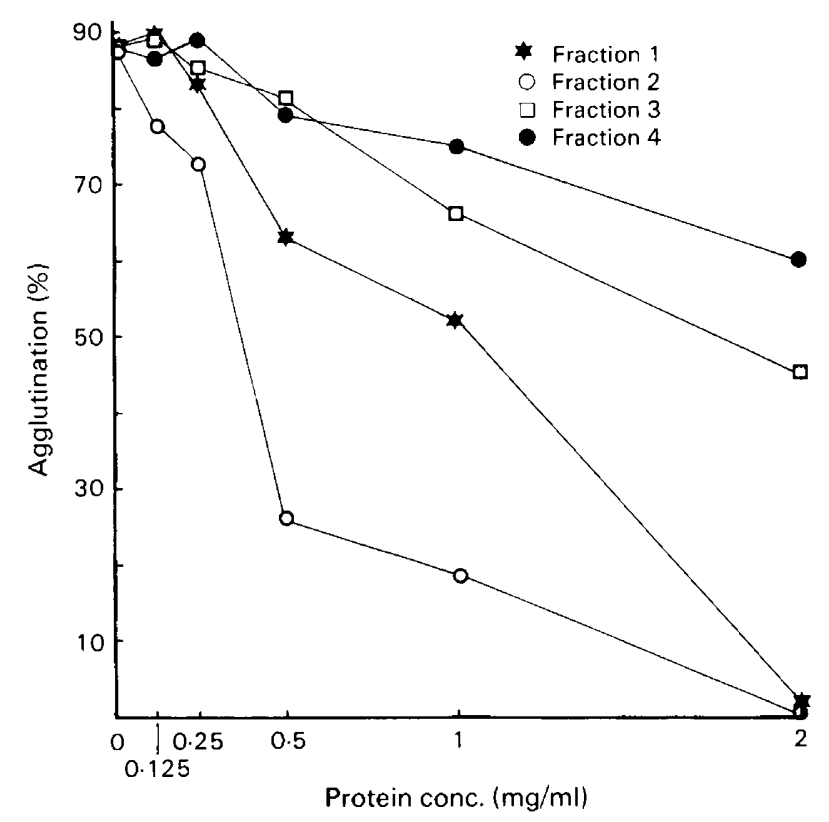

Text-fig. 4. Effect of varying the concentration of protein from the 4 Sephadex fractions of boar cauda epididymal plasma (Text-fig. $3 b$ ) on the agglutination of spermatozoa from epididymal Zones 4-5. The sperm samples were incubated at $37^{\circ} \mathrm{C}$ for $1 \mathrm{~h}$ in $\mathrm{KRB}$. Each value is the average of triplicate estimations. Fraction 2 had the greatest anti-agglutination effect. If the concentrations of protein from the four fractions giving $50 \%$ of agglutination are compared, the values for fractions 4,3 and 1 are, respectively, 6.95, 4.63 and 2.7 times less active than fraction 2 .

The fractionation of boar cauda epididymal plasma on DEAE Sephacel is shown in Text-fig. 5; anti-agglutination activity was found in the last 4 peaks, suggesting that the active material is polymorphic.

\section{Discussion}

Agglutination of epididymal spermatozoa has not previously been studied in terms of the epididymal maturation process but has been often described in experiments using mature spermatozoa (Lindahl, Kihlstrom \& Mag, 1954; Bedford, 1970; Lindahl, 1978; Dott, Harrison \& Foster, 1979; Bullimore, Crich \& Jequier, 1981 ; Lindahl \& Sjöblom, 1981 ; Senger, McCutchan \& 


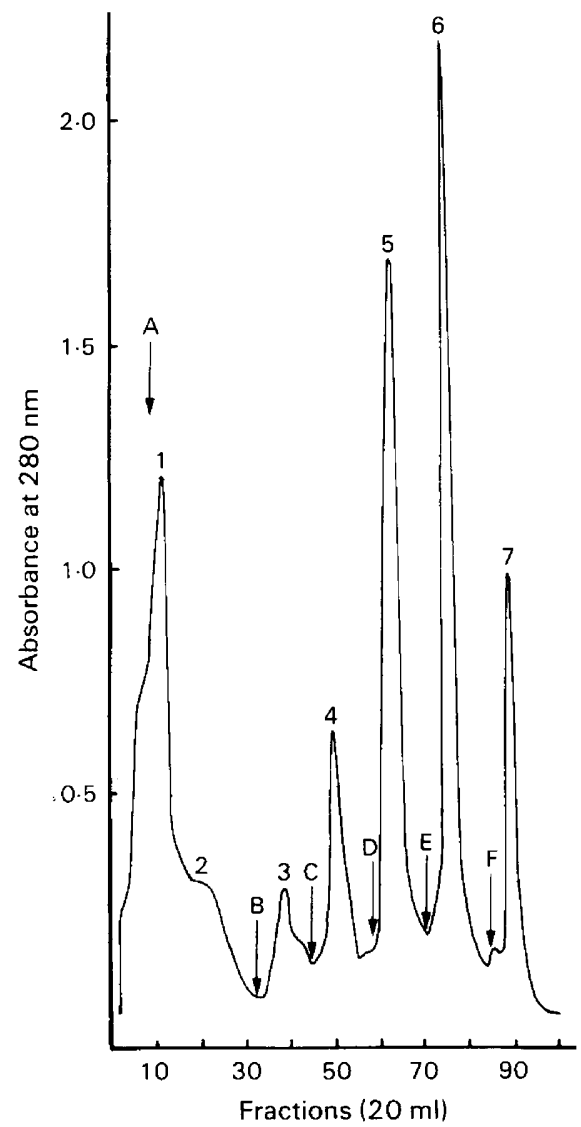

Text-fig. 5. Ion-exchange chromatography of boar cauda epididymal plasma on DEAE Sephacel. The column $(2.5 \times 2.7 \mathrm{~cm})$ was equilibrated with $1 \mathrm{mM}-\mathrm{Tris}-\mathrm{HCl}, \mathrm{pH} 7.9$ at $4^{\circ} \mathrm{C}$ before loading with $818 \mathrm{mg}$ dialysed and freeze dried plasma dissolved in $200 \mathrm{ml} 10 \mathrm{mM}$-Tris$\mathrm{HCl}, \mathrm{pH} \mathrm{8 \cdot 15}$. The letters on the figure indicate the fractions at which the different solutions were applied: A, $10 \mathrm{~mm}$-Tris- $\mathrm{HCl} ; \mathrm{B}, 20 \mathrm{~mm}-\mathrm{NaCl}$ in $\mathrm{A} ; \mathrm{C}, 50 \mathrm{mM}-\mathrm{NaCl}$ in A; D, $100 \mathrm{mM}$ $\mathrm{NaCl}$ in $\mathrm{A} ; \mathrm{E}, 200 \mathrm{~mm}-\mathrm{NaCl}$ in $\mathrm{A} ; \mathrm{F}, 1 \mathrm{M}-\mathrm{NaCl}$ in A. Yields: fraction $1,236 \mathrm{mg} ; 2,200 \mathrm{mg} ; 3$, $92 \mathrm{mg} ; 4,79 \mathrm{mg} ; 5,132 \mathrm{mg} ; 6,120 \mathrm{mg} ; 7,41 \mathrm{mg}$.

Hillers, 1981). There is no agglutination factor in the native epididymal fluid but it appears when gametes are dispersed in an incubation medium. The fact that epididymal spermatozoa carefully collected without blood contamination still showed agglutination indicates that this is a specific property of the spermatozoa and the epididymal environment.

The head-to-head agglutination probably results from a dilution effect by salt solution as described by Dott \& Walton (1960) for ejaculated spermatozoa of rams. During agglutination of spermatozoa from rams and boars, only the membrane overlying the acrosomal region is involved, as has been previously observed with ejaculated bovine spermatozoa in the presence of serum (Senger \& Saacke, 1976). Head-to-head agglutination is only observed in specific regions of the epididymis, e.g. when gametes are taken from the posterior caput and from the corpus, where it is maximal, and it completely disappears in the cauda, probably reflecting two different modifications of the spermatozoa during epididymal transit. Testicular spermatozoa that are diluted or intensively washed never exhibit intense head-to-head agglutination and it can be reasonably assumed that the appearance of agglutination of the spermatozoa in the corpus epididymidis is 
related to a progressive modification of the membrane of the acrosomal region. The fact that the head-to-head agglutination appears only after dilution suggested that there is a compound(s) in the epididymal fluid that prevents agglutination in vivo. The existence of such a compound was further demonstrated by the partial purification of an anti-agglutination factor from cauda epididymal fluid. In contrast, no anti-agglutination activity was found in rete testis fluid. The disappearance of agglutination during the transit of spermatozoa along the cauda epididymidis suggests either that the concentration of the anti-agglutinin increases in the cauda or that it accumulated at the surface of the spermatozoa. The two hypotheses are not mutually exclusive and both support the observation that agglutination can be initiated in spermatozoa from the cauda epididymidis by intensive washing.

The epididymal region where head-to-head agglutination appears (distal caput) was also the region where the spermatozoa began to move. In this same region, Hoskins, Brandt \& Acott (1978) reported the induction of forward motility of the spermatozoa in the presence of theophylline and a cauda epididymal protein. However, the anti-agglutination factor is probably different from the forward motility protein because the former is partly destroyed by heating and forward progressive motility of spermatozoa was always observed in the proximal cauda where agglutination could no longer be observed. Head-to-head agglutination of spermatozoa appeared before they were able to bind intensively to eggs. In boars, spermatozoa were able to attach to zona-free hamster eggs once they had reached the corpus, where agglutination is intensive (Zones 4, 5 and 6) and maximal egg binding ability was observed for Zones 8,9 and 10 where there was little agglutination. Therefore, the changes in surface structures of spermatozoa allowing adherence to zona pellucida seem to be different from those inducing head-to-head agglutination.

The physiological role of the epididymal fluid anti-agglutinin(s) is unknown. Human ejaculated spermatozoa that show head-to-head agglutination exhibit low fertility (Halim \& Antoniov, 1973) but this has not been shown for all the species studied (Bedford, 1970). An antagglutinin has been isolated from the ejaculates of several species (Lindahl et al., 1954), including man (Bullimore et al., 1981) but the occurrence of head-to-head agglutination of ejaculated spermatozoa may not be related to an epididymal antagglutinin deficiency because such a factor has also been found in prostatic secretions of the bull (Lindahl et al., 1954).

The absence of species specificity demonstrated in this study suggests that antagglutinins from all species act on spermatozoa in the same way and may be present in epididymal fluid of other mammals. The purification of such a compound is obviously of interest for studies of the motility of the spermatozoa from the corpus epididymidis since these spermatozoa normally aggregate during the incubation process.

We thank Martine Batailler and Michel Terriot for the help with the manuscript and Dr G. B. Martin for the English translation.

\section{References}

Bedford, J.M. (1963) Changes in the electrophoretic properties of rabbit spermatozoa during passage through the epididymis. Nature, Lond. 200, 11781180.

Bedford, J.M. (1966) Development of the fertilizing ability of spermatozoa in the epididymis of the rabbit. J. exp. Zool. 163, 319-329.

Bedford, J.M. (1970) Observations on some properties of a potent sperm-head agglutinin in the semen of a fertile rabbit. J. Reprod. Fert. 22, 193-198.

Bullimore, N.J., Crich, J.P. \& Jequier, A.M. (1981) The isolation of a possible antagglutinin from human semen. Andrologia 13, 387-394.
Dacheux, J.L. (1980) An in vitro luminal perfusion technique to study epididymal secretion. IRCS Med. Sci. 8, 137

Dacheux, J.L. \& Paquignon, M. (1980) Relation between the fertilizing ability, motility and metabolism of epididymal spermatozoa. Reprod. Nutr. Development 20, 1085-1099.

Dacheux, J.L., O'Shea, T. \& Paquignon, M. (1979) Effects of osmolality bicarbonate and buffer on the metabolism and motility of testicular, epididymal and ejaculated spermatozoa of boars. J. Reprod. Fert. 55, 287-296. 
Dott, H.M. \& Walton, A. (1960) Effects of dilution and washing on ram spermatozoa studied by the flow dialysis technique. J. Reprod. Fert. 1, 350-367.

Dott, H.M., Harrison, R.A.P. \& Foster, G.C.A. (1979) The maintenance of motility and the surface properties of epididymal spermatozoa from bull, rabbit and ram in homologous seminal and epididymal plasma. J. Reprod. Fert. 55, 113-124.

Dubois, M., Jouannet, P., Berge, P., Volochine, B., Serres, C. \& David, G. (1975) Methode et appareillage de mesure objective de la mobilité des spermatozoïdes humains. Ann. Phys. Biol. Med. 9, 19-41.

Franchimont, P., Chari, S., Hazee-Hagelstein, M.T., Debruche, M.L. \& Duraiswami, S. (1977) Evidence for the existence of inhibin. In The Testis in Normal and Infertile Men, pp. 253-270. Eds P. Troen \& H.R. Nankin. Raven Press, New York.

Gaddum, P. (1968) Sperm maturation in the male reproductive tract: Development of motility. Anat. Rec. 161, 471-482.

Halim, A. \& Antoniov, D. (1973) Autoantibodies to spermatozoa in relation to male infertility and vasectomy. Br. J. Urol. 45, 559-562.

Hanada, A. \& Nagase, H. (1981) Effects of sperm preincubation in rabbit uterus and of imidazole on the penetration of zona-free hamster eggs by bull and boar spermatozoa in vitro. Japan. J. Anim. Reprod. 27, 113-118.

Hoskins, D.D., Brandt, H. \& Acott, T.S. (1978) Initiation of sperm motility in the mammalian epididymis. Fedn Proc. Fedn Am. Socs exp. Biol. 37, 2534-2542.

Imai, H., Niwa, K. \& Iritani, A. (1977) Penetration in vitro of zona-free hamster eggs by ejaculated spermatozoa. J. Reprod. Fert. 51, 495- 497.

Imai, H., Niwa, K. \& Iritani, A. (1979) Time requirement of capacitation of boar spermatozoa assessed by their ability to penetrate the zona-free hamster egg. $J$. Reprod. Fert. 56, 489-492.

Imai, H., Niwa, K. \& Iritani, A. (1980) Ultrastructural observations of boar spermatozoa penetrating zona free hamster egg. Biol. Reprod. 23, 481-486.

Jouannet, P., Volochine, B., Deguent, P., Serres, C. \& David, G. (1977) Light scattering determination of various characteristic parameters of spermatozoa motility in a serie of human sperm. Andrologia 9, 3645.

Lewin, L.M., Weissenberg, R., Sobel, J.S., Marcus, Z. \& Nebel, L. (1979) Differences in concanavalin AFITC binding to rat spermatozoa during epididymal maturation and capacitation. Arch. Androl. 2, 279 281.

Lindah!, P.E. (1978) Head-to-head association in bovine spermatozoa induced by catecholamines. Expl Cell Res. 113, 421-433.
Lindahl, P.E. \& Sjöblom, P. (1981) On mechanisms of head-to-head association in bovine spermatozoa. Biol. Reprod. 25, 29-43.

Lindahl, P.E., Kihlstrom, J.E. \& Mag, Ph. (1954) An antiagglutinic factor in mammalian sperm plasma. Fert. Steril. 5, 241-255.

Nicolson, G.L., Usui, N., Yanagimachi, E., Yanagimachi, H. \& Smith, J.R. (1977) Lectin binding sites on the plasma membrane of rabbit spermatozoa. Changes in surface receptors during epididymal maturation and after ejaculation. J. Cell Biol. 74, 950-962.

Olson, G.E. \& Hamilton, D.W. (1978) Characterization of the surface glycoproteins of rat spermatozoa. Biol. Reprod. 19, 26-35.

Orgebin-Crist, M.C. (1967) Maturation of spermatozoa in the rabbit epididymis: fertilizing ability and embryonic mortality in does inseminated with epididymal spermatozoa. Annls Biol. anim. Biochim. Biophys. 7, 373-389.

Orgebin-Crist, M.C., Olson, G.E. \& Danzo, B.J. (1981) Factors influencing maturation of spermatozoa in the epididymis. In Intragonadal Regulation of Reproduction, pp. 399 417. Eds C. P. Channing \& P. Franchimont. Academic Press, New York.

Schmell, E.D. \& Gulyas, B.J. (1980) Mammalian spermegg recognition and binding in vitro. I. Specificity of sperm interaction with live and fixed eggs in homologous and heterologous insemination of hamster, mouse and guinea pig oocytes. Biol. Reprod. 23, 1075-1085.

Senger, P.L. \& Saacke, R.G. (1976) Serum induced headto-head agglutination of bovine spermatozoa. $J$. Reprod. Fert. 47, 215-219.

Senger, P.L., McCutchan, J.F. \& Hillers, J.K. (1981) Influence of blood serum from bulls and heifers on head-to-head agglutination and acrosomal maintenance in bovine spermatozoa. Biol. Reprod. 25, 433437.

Suarez, S.S., Hinton, B.T. \& Oliphant, G. (1981) Binding of a marker for immunoglobulins to the surface of rabbit testicular, epididymal and ejaculated spermatozoa. Biol. Reprod. 25, 1091-1097.

Voglmayr, J.F., Waites, G.M.H. \& Setchell, B.P. (1966) Studies on spermatozoa collected directly from the testis of the conscious ram. Nature, Lond. 210, 861863.

Voglmayr, J.F., Scott, T.W., Setchell, B.P. \& Waites, G.M.H. (1967) Metabolism of testicular spermatozoa and characteristics of testicular fluid collected from conscious rams. J. Reprod. Fert. 14, 87-99.

Yanagimachi, R., Yanagimachi, H. \& Rogers, B.J. (1976) The use of zona free animal ova as a test-system for the assessment of the fertilizing capacity of human spermatozoa. Biol. Reprod. 15, 471-476. 